\title{
Morphological measurements of Atlantic puffin (Fratercula arctica naumanni) in High-Arctic Greenland
}

\author{
Kurt K. Burnham ${ }^{1}$ (D) Jennifer L. Burnham² (1) \& Jeff A. Johnson ${ }^{3}$ (i) \\ 'High Arctic Institute, Orion, IL, USA; \\ ${ }^{2}$ Department of Geography, Augustana College, Rock Island, IL, USA; \\ ${ }^{3}$ Department of Biological Sciences, University of North Texas, Denton, TX, USA
}

\begin{abstract}
Morphological measurements of 45 adult Atlantic puffins Fratercula arctica were collected in High-Arctic Greenland between 2010 and 2016. Measurements support that the population belongs to the $F$. a. naumanni subspecies and were significantly larger than those from populations found at lower latitudes, including F. a. grabae and F. a. arctica populations. Male puffins from High-Arctic Greenland had greater mass, bill length and tarsus length than females, but no difference was found in wing length. In comparison to other naumanii populations, body size was most similar to puffins in Svalbard. Overall, the measured Atlantic puffins from High-Arctic Greenland had some of the largest and most variable morphological measurements reported for any studied Atlantic puffin population. While morphological measurements and the relative geographic isolation of the puffin population in High-Arctic Greenland support the naumanni subspecies designation, additional research should use genetic methods to determine if this population and other populations in the North Atlantic are isolated. This is the only collection of naumanni morphometric measurements from geographical North America and enhances our collective knowledge of the species.
\end{abstract}

\section{Keywords}

Sexual dimorphism; cline; grabae; Bergmann's Rule; bird size

\section{Correspondence}

Kurt K. Burnham, High Arctic Institute, 603 10th Avenue, Orion, IL 61273, USA. E-mail: kburnham@higharctic.org

\section{Abbreviations}

ANOVA: analysis of variance statistical test SD: standard deviation

\section{Introduction}

The Atlantic puffin (Fratercula arctica; hereafter referred to as puffin) is a medium-sized auk found in the North Atlantic, with a breeding range extending north from the Gulf of Maine, USA $\left(43^{\circ} \mathrm{N}\right)$ and Brittany, France $\left(50^{\circ} \mathrm{N}\right)$ to north-west Greenland $\left(77^{\circ} \mathrm{N}\right)$, Svalbard, Norway $\left(80^{\circ} \mathrm{N}\right)$ and Novaya Zemlya, Russia $\left(76^{\circ} \mathrm{N}\right.$; Fig. 1; Gaston \& Jones 1998; Harris \& Wanless 2011). Although the global population is estimated at 12-14 million adults (Harris \& Wanless 2011; Berglund \& Hentati-Sundberg 2015), the species is listed globally as vulnerable and currently in decline, with very low productivity reported recently for many breeding colonies (BirdLife International 2020). Over 90\% of the global population is in Europe, with Iceland and Norway accounting for $80 \%$ (BirdLife International 2020). Colony sizes range from a few breeding pairs in the High Arctic of eastern North America (e.g., north-west Greenland and north-east Canada; Salomonsen 1950; Robards et al. 2000) to over a million in the Westman Islands, Iceland (Hansen \& Garrðarsson 2009); some colonies have significantly decreased in size over the past few decades (e.g., Røst, Norway; Harris \& Wanless 2011 ; BirdLife International 2020).

The taxonomic nomenclature of Atlantic puffin has varied throughout much of the 20th century, but generally the species includes three subspecies (F. a. grabae, arctica and naumanni), largely differentiated by body size (e.g., bill, wing and mass) and geographic location (for review, see Salomonsen 1944; Vaurie 1965; Harris $\&$ Wanless 2011). The puffins of the British Isles, Faroe Islands, France, the English Channel Islands and southern Norway are designated F. a. grabae and are the smallest in size, whereas individuals in Iceland, northern Norway, southern Greenland, Canada and the US are considered F. a. arctica and are of intermediate size (Fig. 1). Puffins nesting in High-Arctic Greenland, Svalbard (excluding Bjørnøya) and Novaya Zemlya are distinctly larger than those in the south and are commonly referred to as "large-billed" puffins or the F. a. naumanni subspecies (Fig. 1). Puffins breeding on the Norwegian islands of Jan Mayen and Bjørnøya, the latter the southernmost island in the Svalbard Archipelago, are generally considered 


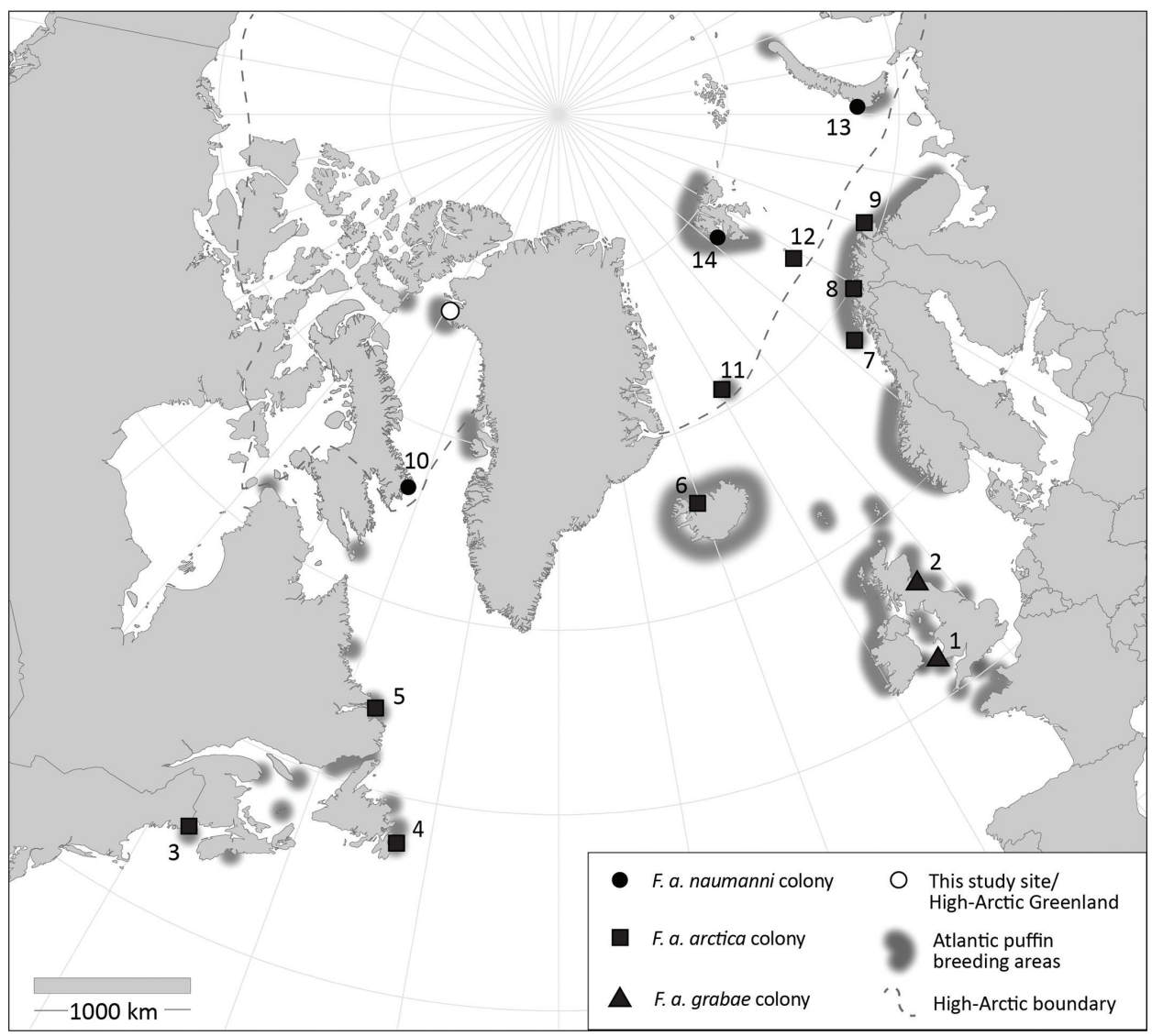

Fig. 1 Breeding distribution of Atlantic puffin (Fratercula arctica) and locations of places mentioned in the text and Table 2 are as follows. (1) Skomer Island; (2) Isle of May; (3) Machias Seal Island; (4) Gull Island; (5) Gannet Islands; (6) Baer; (7) Røst; (8) Troms; (9) Hornøy; (10) Baffin Island (single naumanni individual collected, possible colony present but of unknown subspecies); (11) Jan Mayen; (12) Bjørnøya; (13) Novaya Zemyla; (14) Svalbard (main group of islands). Figure based on Gaston \& Jones (1998) and Lowther et al. (2020). High-Arctic boundary from Kurvits et al. (2010).

intermediate between arctica and naumanni, and, depending upon the morphological data set used, arguments could be made for their inclusion as either subspecies (Schaanning 1933; Salomonsen 1944; Holgersen 1953; Camphuysen 1989).

These subspecies designations have become contentious. Bédard (1985) found no support for subspecies designations based on morphology, while Moen (1991) came to a similar conclusion on the basis of genetic differentiation using allozymes and morphology. Both concluded that the apparent latitudinal increase in body size represented a cline within a single panmictic population (i.e., Bergmann's Rule; Myrberget 1963), which has also been suggested by others (e.g., Pethon 1967; Barrett et al. 1985). However, its extremely large body size makes the naumanni subspecies unique from individuals farther south in the species' geographic distribution. In their seminal book, The puffin, Harris \& Wanless (2011) recommend that the naumanni subspecies should be retained until more comprehensive analyses address the issue of its morphological distinctness.

Published historical morphology measurements of $F$. a. naumanni are scarce. Data from Svalbard and Novaya Zemlya are limited to ca. 144 and ca. 14 samples, respectively (Kolthoff 1903; Le Roi 1911; Salomonsen 1944; Dement'ev et al. 1951; Vaurie 1965; Pethon 1967; de Korte 1972; Harris 1984). Data from HighArctic Greenland are even scarcer. The only published morphological records appear to be wing measurements of two males (Salomonsen 1935). All of these F. a. naumanni samples were collected over a half a century ago, and some specimens were collected as long ago as the 1860s. The only published morphometric data for contemporary F. a. naumanni samples are from Gaston $\delta$ Provencher (2012) and Underwood (2019) for a single Canadian and 16 Svalbard puffins, respectively. The paucity of $F$. a. naumanni measurements, particularly for contemporary samples and from High-Arctic Greenland, 
makes statistical comparisons between populations less informative if not impossible.

Puffins in Greenland are found almost exclusively on the west coast and breed from Kitsissut Avalliit $\left(60^{\circ} \mathrm{N}\right)$ to the High Arctic of the Avanersuaq District $\left(76.5^{\circ} \mathrm{N}\right)$, with an estimated population size of 5000 pairs (Boertmann 1994, 2007; Boertmann et al. 1996; Boertmann et al. 2020). The Greenland population is considered Near Threatened and in decline (Boertmann 2007), yet the only annual surveys conducted are from the Avanersuaq District (this study), and information from other colonies elsewhere in Greenland is generally collected anecdotally (Boertmann 1994; Boertmann et al. 1996). All of what is currently known concerning puffin morphometrics in Greenland was provided by Salomonsen (1944, 1950).

The most northern population of puffins in the western North Atlantic is found within the Avanersuaq District in the High Arctic of north-west Greenland (Boertmann et al. 1996). Seven colonies are known in the area, ranging in size from a few individuals to approximately 75 pairs (Boertmann et al. 1996; Burnham \& Burnham 2010; K. Burnham unpubl. data). Here, we provide data from seven years of morphometric measurements collected at the second largest breeding colony in the High Arctic of north-west Greenland. These data are important to determine whether there are differences in body size between puffin colonies within and among subspecies designations.

\section{Methods}

Adult Atlantic puffins were studied from 2010 to 2016 at Dalrymple Rock (Igánaq; 76²8'21.65"N, 70¹3'12.40"W; Fig. 1), an island in the High Arctic and the site of one of the seven known breeding colonies in the Avanersuaq District in north-west Greenland. The puffin colony has an estimated 15-35 pairs that arrive at the end of May and depart by mid- to late September (K. Burnham unpubl. data). Unlike colonies to the south in eastern North America and Europe, puffins on Dalrymple Rock are unable to excavate burrows on the account of near surface permafrost; they nest in rock crevices on cliff faces or under boulders (Salomonsen 1950; K. Burnham unpubl. data). Although no information is known about the breeding chronology of our study colony, we documented, through camera-trapping, a chick fledge on 13 September 2017 (K. Burnham unpubl. data).

Using a combination of dip nets and noose carpets, puffins were captured from 3 July to 10 August. After capturing, puffins were weighed, measured, banded (Danish government leg band and colour band) and sampled (feathers and blood), after which all were released unharmed. Age was determined using bill grooves, a technique described by Harris (1981, 1984), and individuals with at least two bill grooves were considered adults. All puffins were sexed using a standard molecular method described elsewhere (Bond et al. 2016), using primers 2550F and 2718R (Fridolfsson \& Ellegren 1999) and DNA extracted from either blood or breast feathers using the DNeasy Blood and Tissue Kit (Qiagen Inc.).

Wing length was measured to the nearest $1 \mathrm{~mm}$ using a stopped wing ruler, and the right wing was flattened and straightened prior to measurement following Gosler (2004). Bill length was measured to the nearest $0.01 \mathrm{~mm}$ using digital calipers as the distance from the tip of the bill to the distal edge of the cere. Tarsus length was measured to the nearest $0.01 \mathrm{~mm}$ using digital calipers following procedures described by Gosler (2004) for "minimum tarsus." Mass was measured to the nearest $5 \mathrm{~g}$ or $10 \mathrm{~g}$ using either a $600 \mathrm{~g}$ or $1000 \mathrm{~g}$ spring balance, respectively. Measurements from initial capture for each puffin were used to calculate mean body size provided in Table 1 and for all analysis except when noted otherwise.

Minitab (version 19.2; Minitab LLC) was used to conduct statistical analysis. All data were tested for normality, and tests with a $p$ value below 0.05 were considered significant unless otherwise noted. Linear regression was used to test for relationships between capture date and mass and for annual changes in mean mass, while

Table 1 Average adult Atlantic puffin body size measurements collected from 2010 to 2015 at Dalrymple Rock, High-Arctic Greenland

\begin{tabular}{|c|c|c|c|c|}
\hline & $\begin{array}{c}\text { Mass }(g) \text { mean } \pm S D \\
n, \text { range }\end{array}$ & $\begin{array}{l}\text { Bill length }(\mathrm{mm}) \text { mean } \pm \mathrm{SD} \\
n \text {, range }\end{array}$ & $\begin{array}{c}\text { Tarsus length }(\mathrm{mm}) \text { mean } \pm S D \\
n \text {, range }\end{array}$ & $\begin{array}{c}\text { Wing length }(\mathrm{mm}) \text { mean } \pm \mathrm{SD} \\
n \text {, range }\end{array}$ \\
\hline \multirow{2}{*}{ Male } & $563 \pm 62.1$ & $51.9 \pm 2.3$ & $37.8 \pm 1.4$ & $185.0 \pm 7.7$ \\
\hline & $22,444-716$ & $22,47.9-56.1$ & $22,34.5-40.2$ & $22,168-198$ \\
\hline \multirow{2}{*}{ Female } & $526 \pm 51.3$ & $49.4 \pm 2.2$ & $36.9 \pm 1.2$ & $182.0 \pm 6.1$ \\
\hline & $22,426-611$ & $22,44.6-53.2$ & $21,34.6-39.2$ & $23,170-192$ \\
\hline $\begin{array}{l}\text { One-way ANOVA, } \\
\text { males vs. females }\end{array}$ & $\begin{array}{c}F_{1,42}=5.49 \\
p=0.04\end{array}$ & $\begin{array}{c}F_{1,42}=13.84 \\
p=0.001\end{array}$ & $\begin{array}{c}F_{1,41}=4.76 \\
p=0.04\end{array}$ & $\begin{array}{c}F_{1,43}=2.09 \\
p=0.16\end{array}$ \\
\hline \multirow{2}{*}{ Sexes combined } & $545 \pm 59.2$ & $50.7 \pm 2.6$ & $37.3 \pm 1.4$ & $183.5 \pm 7.0$ \\
\hline & $44,426-716$ & $44,44.6-56.1$ & $43,34.6-40.2$ & $45,168-198$ \\
\hline
\end{tabular}


paired $t$-tests were used to test for differences in mass among individuals captured in multiple years. A oneway ANOVA was used to test for morphometric differences between male and female puffins within the focal study colony, and a Pearson correlation was used to test for association between variables. Two-tailed $t$-tests and a Bonferroni-corrected $p$ value of 0.002 were used for comparisons of data from our study colony and summary data for other puffin colonies that have been reported elsewhere (see Table 2), and only measurements with a mean, standard deviation and known sample size were included in the analyses.

\section{Results}

Twenty-two male and 23 female adult puffins were captured on 61 different occasions between 2010 and 2016 (only recaptures in 2016). Capture dates ranged from 3 July to 10 August $(\bar{x}=22$ July, SD \pm 9.1$)$. All captured birds had at least two bill grooves; no juveniles or subadults were observed or captured. Marked individuals were commonly observed coming and going from apparent nests, although no adults were observed returning to the colony with fish in their bills, suggesting that our surveys were conducted primarily during the population's incubation period.

No significant correlation was found between mass and capture date for male and female puffins $(p=0.98$, $r^{2}=0.00, n=22 ; p=0.16, r^{2}=0.10, n=22$; respectively) or change in annual mean mass for both males and females $\left(p=0.27, r^{2}=0.00, n=17 ; p=0.85, r^{2}=0.06\right.$, $n=22$; respectively) based on measurements collected between 2010 and 2015. For individuals captured in multiple years ( $1-5$ years between captures), no difference in mass was observed between capture years for either male (paired $t$-test, $t_{6}=1.81, p=0.12, n=7$ ) or female puffins (paired $t$-test, $t_{7}=0.19, p=0.86, n=8$ ); however, sample sizes were low.

Adult male puffins were significantly larger than females. Males were an average of $36 \mathrm{~g}$ heavier and had $2.5 \mathrm{~mm}$ and $0.9 \mathrm{~mm}$ longer bill and tarsus lengths, respectively (Table 1, Fig. 2). Male wings averaged $3.0 \mathrm{~mm}$ longer than females, but this apparent difference was not statistically significant (Table 1). Tarsus measurements had the greatest overlap between males and females, $80.7 \%$, followed by wing, mass and bill $(73.3 \%$, $61.0 \%$ and $46.1 \%$, respectively; Fig. 2). Minimum wing and tarsus lengths of males were shorter than females by $2.0 \mathrm{~mm}$ and $0.1 \mathrm{~mm}$, respectively, but minimum mass and bill lengths were smaller for females by $18 \mathrm{~g}$ and $3.3 \mathrm{~mm}$, respectively (Table 1, Fig. 2). When morphological data for both sexes were combined, strong and significant correlations existed between all pairwise comparisons except wing and tarsus (Fig. 3).

The size of the measured puffins from High-Arctic Greenland was generally larger than those found at more southern latitudes in both eastern North America and Europe. When compared with puffins at colonies in Canada (Machias Seal Island, Gull Island and the Gannet Islands), puffins from High-Arctic Greenland were significantly larger for all measurements except bill length at the Gannet Islands $\left(t_{57}=1.90, p=0.06\right.$; see Table 2 for individual statistical comparisons and reference). Comparisons with puffin colonies in the UK (Skomer Island and Isle of May), Iceland (Baer) and Norway (Røst, Troms and Hornøy) yielded similar results with puffins from High-Arctic Greenland being significantly larger for all measurements except bill length at Baer $\left(t_{23}=2.99\right.$, $p=0.007$; Table 2).

Among F. a. naumanni in the High Arctic, comparisons with historical data from Svalbard (Le Roi 1911) showed no difference in wing length $\left(t_{82}=-0.76, p=0.45\right)$, although Svalbard puffins had longer bills $\left(t_{82}=-7.10\right.$, $p<0.001$ ). Comparison with contemporary data (Underwood 2019) varied slightly, with no observed difference in bill or wing length $\left(t_{46}=-0.55, p=0.58 ; t_{55}=-1.52\right.$, $p=0.13$; respectively), yet Svalbard puffins were on average $39 \mathrm{~g}$ heavier $\left(t_{57}=-3.87, p<0.001\right.$; Table 2$)$. Aside from Svalbard, there are no data of sufficient sample size from other High-Arctic populations that allow for statistical comparison.

The range of mass of individual puffins from HighArctic Greenland (290 g, 426-716) was greater than any other colony included in this analysis. Røst, with a range of $245 \mathrm{~g}$ (340-585), was next closest, although their sample size was much greater ( $n=44$ vs. 2381; Table 2, Fig. 4). Similar patterns of large range were observed for bill length, though to a lesser degree, and only Svalbard puffins had an equal range of wing length (Table 2, Fig. 4).

\section{Discussion}

Adult puffins from our study colony were significantly larger than those occurring outside High-Arctic North America and Europe. In some instances, the mass of individuals from our study colony was more than double that of individuals from more southern colonies, which agrees with what has been described by Salomonsen (1944, 1950), Vaurie (1965) and Harris \& Wanless (2011) for the larger High-Arctic naumanni subspecies. When compared with limited data from naumanni colonies in Novaya Zemlya and Svalbard, High-Arctic Greenland puffins were larger in size than those from Novaya Zemlya, and 


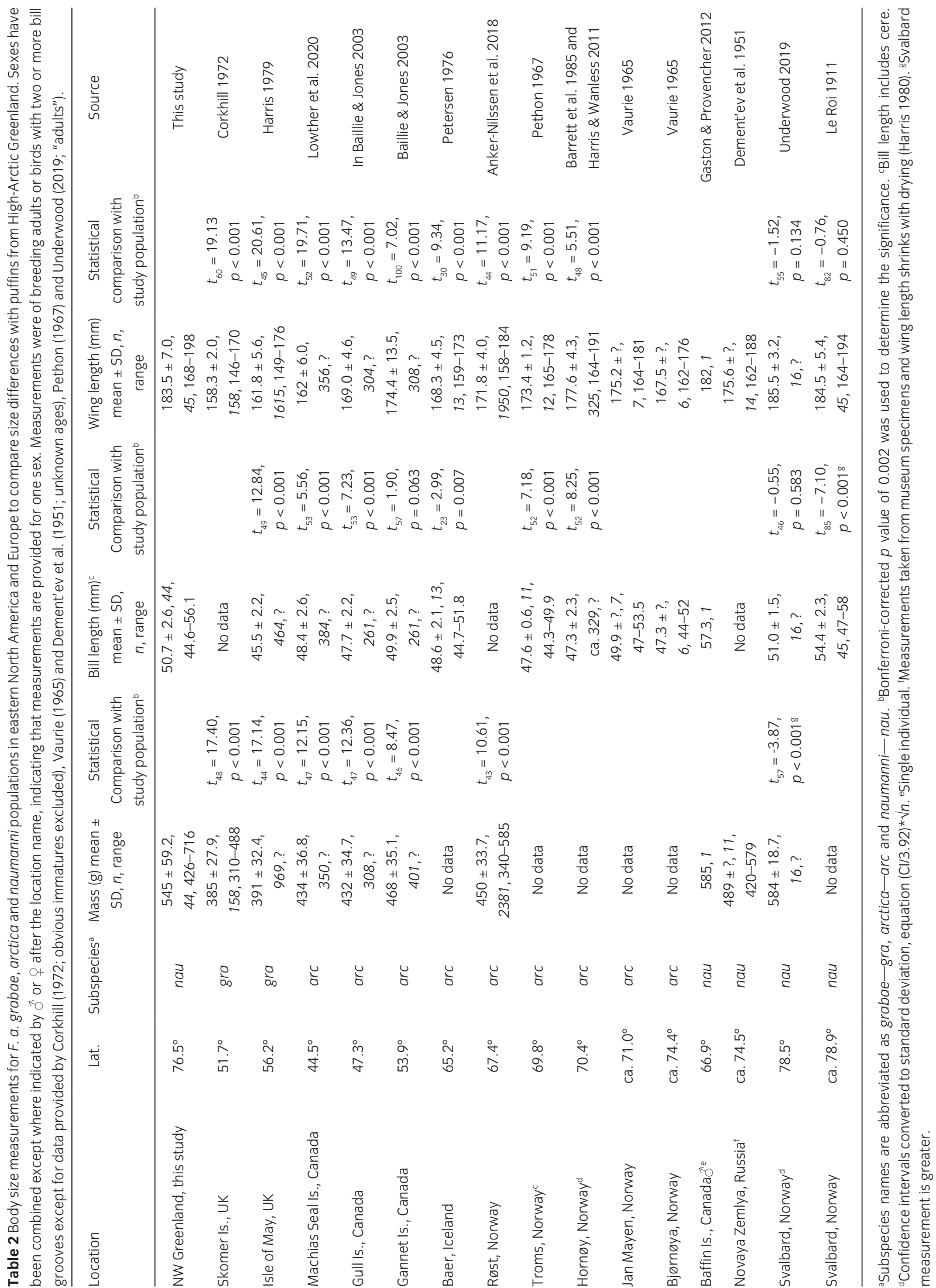



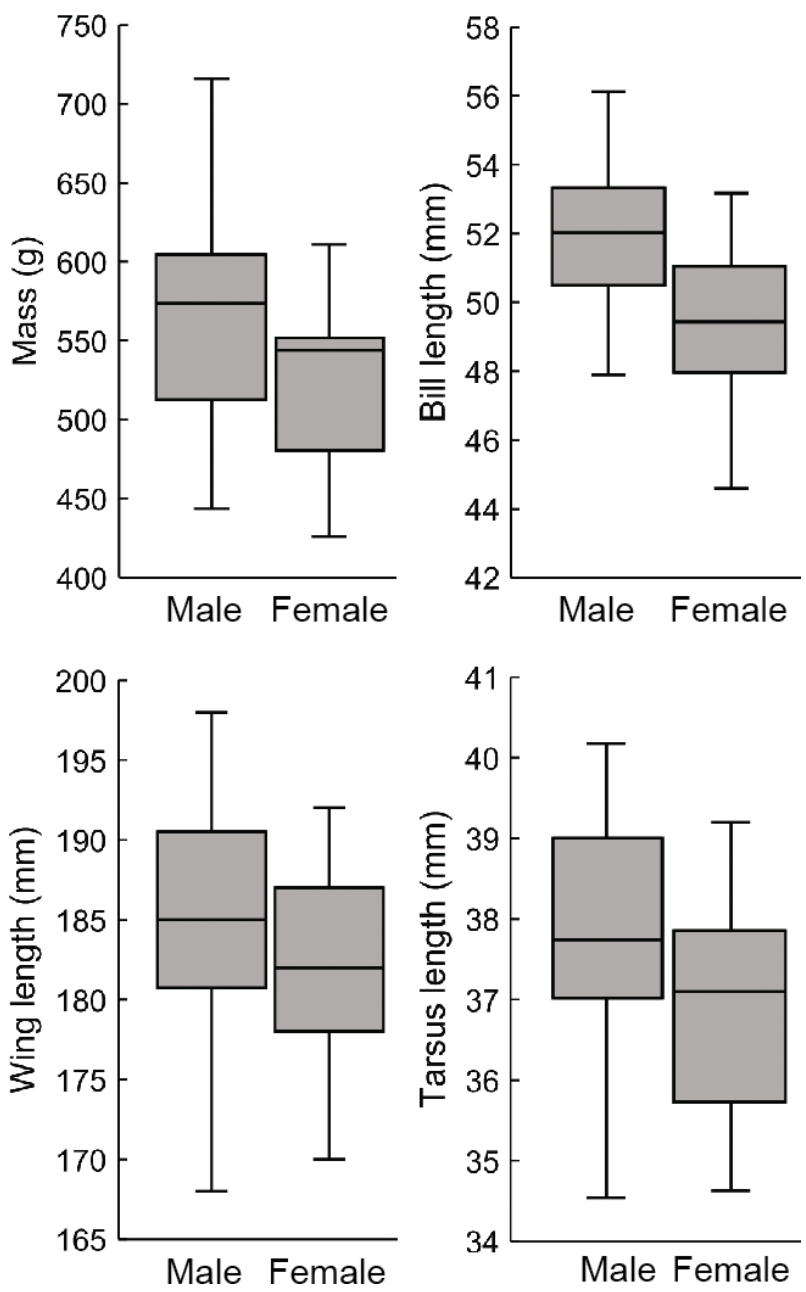

Fig. 2 Boxplots for mass, bill, wing and tarsus length of Atlantic puffins from Dalrymple Rock, High-Arctic Greenland.

most comparable in size to those from Svalbard. Wing lengths of two male specimens from High-Arctic Greenland described by Salomonsen (1935) were $185 \mathrm{~mm}$ and $194 \mathrm{~mm}$, well within the range of male puffins found in this study. Furthermore, the range of morphological measurements of High-Arctic Greenland puffins was greater than for any other breeding colony included in our study.

Throughout their southern breeding range, puffins have been shown to demonstrate a high degree of sexual dimorphism, with males being larger than females (Corkhill 1972; Friars \& Diamond 2011; Harris \& Wanless 2011; Bond et al. 2016). We found similar results for F. a. naumanni in High-Arctic Greenland; however, measurements overlapped considerably, and wing length differences were not significant between the sexes (Fig. 2). Differences in size between $F$. a. naumanni males and females from Svalbard are mixed. Historical data from Vaurie (1965) showed males $(n=24)$ had longer bills
(1.9 $\mathrm{mm})$ and wings $(2.4 \mathrm{~mm})$ than females $(n=24)$. However, contemporary data from Underwood (2019) showed virtually no difference in bill length (females $0.1 \mathrm{~mm}$ longer) and only a small difference in mass (males $19 \mathrm{~g}$ heavier) between males $(n=10)$ and females $(n=6)$, with only wing length showing appreciable differences between the sexes (males $5.3 \mathrm{~mm}$ longer). Additional study is warranted in the Svalbard F. a. naumanni puffin population to determine if the observed pattern persists with a larger sample size.

Temporal trends of body mass change in puffins are spatially varied across the North Atlantic. Previous research showed that puffins lose $5-10 \%$ of their body mass during their approximate three-month breeding season (Harris 1979; Barrett et al. 1985). Our study showed no change in mass for either sex during the sampling period within the breeding season. Neither did we find an annual change in mean mass among either sex over the study period or between capture events for the same individual. Barrett et al. (2012) also found no change in body size of adult puffins at two Norwegian puffin colonies over an approximate 30-year period, despite a significant decrease in egg volume over the same period. A long-term decline in mass, however, was observed in adult puffins on the Isle of May (Harris \& Wanless 2011). Change in adult mean mass in High-Arctic Greenland may be occurring, but our limited sample size and collection period (incubation period only) may prevent us from detecting change.

The lack of observations of juveniles and sub-adults at our study colony can be accounted for by the fact that these young individuals typically do not arrive at the breeding colonies until after eggs hatch (Harris 1983; Harris \& Wanless 2011). As we did not observe adults returning to the colony with fish, our field seasons had likely concluded prior to eggs hatching.

Puffins in High-Arctic Greenland and Svalbard appear to have the largest overall body size of any known population in the world. The only other records for puffins of comparable size are for a single puffin collected on Baffin Island, Canada, during the breeding season (Table 2, Fig. 4), and two puffins collected in the Faroe Islands in winter, which weighed $720 \mathrm{~g}$ and $730 \mathrm{~g}$ and were likely migrants (Gaston \& Provencher 2012; Anker-Nilssen et al. 2018). The wing length of the $730 \mathrm{~g}$ puffin on the Faroe Islands was only $174 \mathrm{~mm}$, relatively short for naumanni (wing length not recorded for other specimens). Puffins have been shown to increase their body mass by 20-30\% outside the chick rearing period (Anker-Nilssen et al. 2018). A male puffin caught during our study weighed $716 \mathrm{~g}$, which is to our knowledge the largest mass recorded for this species during the breeding season. While these contemporary measurements add to the 

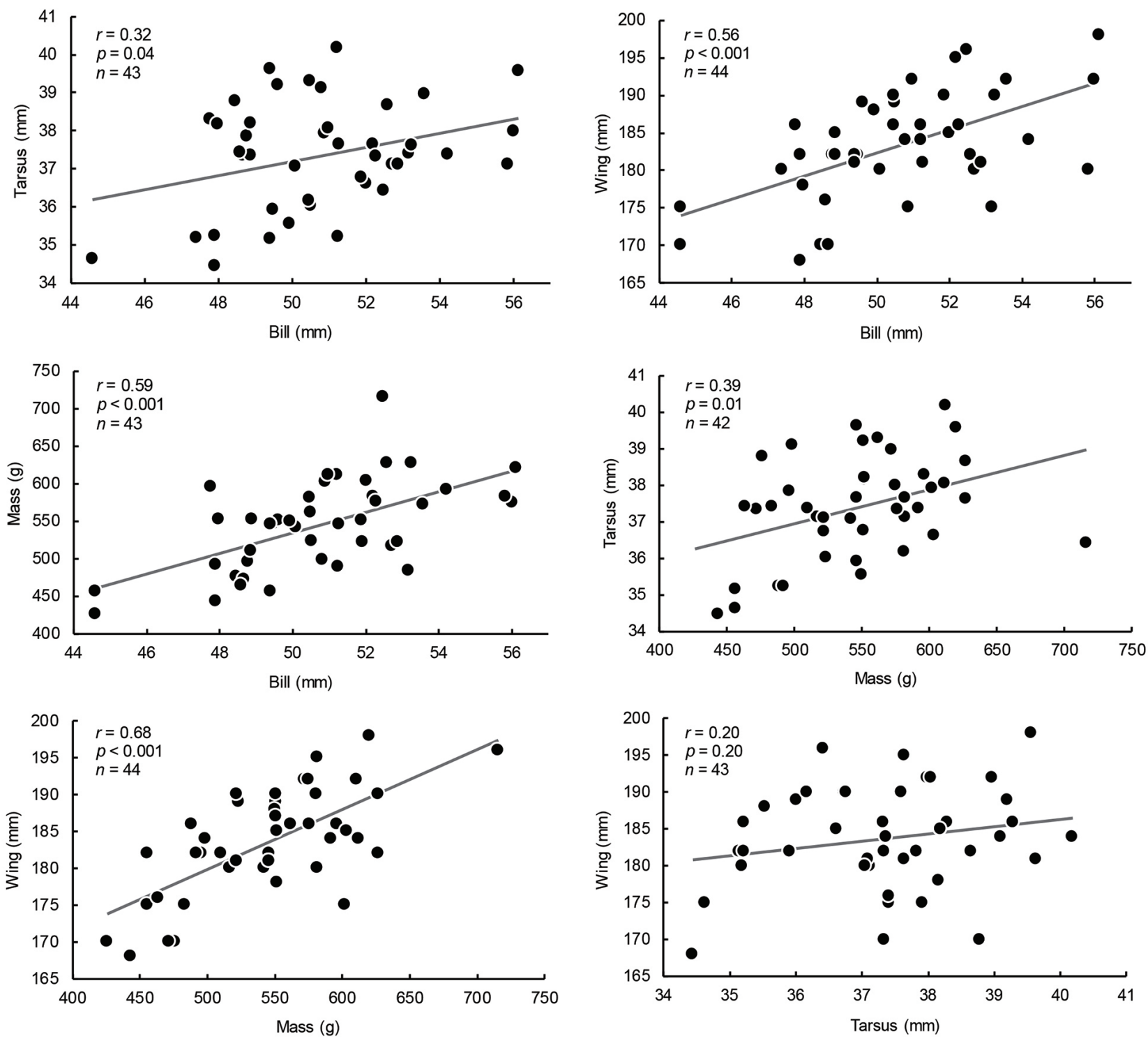

Fig. 3 Correlations between body size measurements for adult male and female Atlantic puffins captured from 2010 to 2015 at Dalrymple Rock, High-Arctic Greenland.

body of literature for F. a. naumanni, additional research is warranted to further investigate possible reasons why the study population exhibits such large body size and overall variation compared with other Atlantic puffin populations.

Bergmann's Rule generally states that within a taxonomic clade body size increases at higher latitudes and in cooler climates (Bergmann 1847), which has been shown generally to apply among birds (Ashton 2002; Meiri $\delta$ Dayan 2003). Barrett et al. (1985) studied 12 puffin colonies in Norway and found strong support for a clinal increase in size based on latitude. Similar conclusions were reached by Harris \& Wanless (2011) for wing length in puffin colonies throughout the eastern $(n=31)$ and western $(n=6)$ Atlantic. Other auk species breeding throughout much the same geographic range as puffins in the North Atlantic also demonstrated clinal relationships with body size, including thick-billed murre (Uria lomvia; Gaston \& Hipfner 2020), little auk (Alle alle; Wojczulanis-Jakubas et al. 2011), razorbill (Alca torda; Barrett et al. 1997; Lavers et al. 2020) and black guillemot (Cepphus grille; Wojczulanis-Jakubas et al. 2011; Butler et al. 2020). While these clinal increases in size fit well with Bergmann's Rule, the exact driving forces 

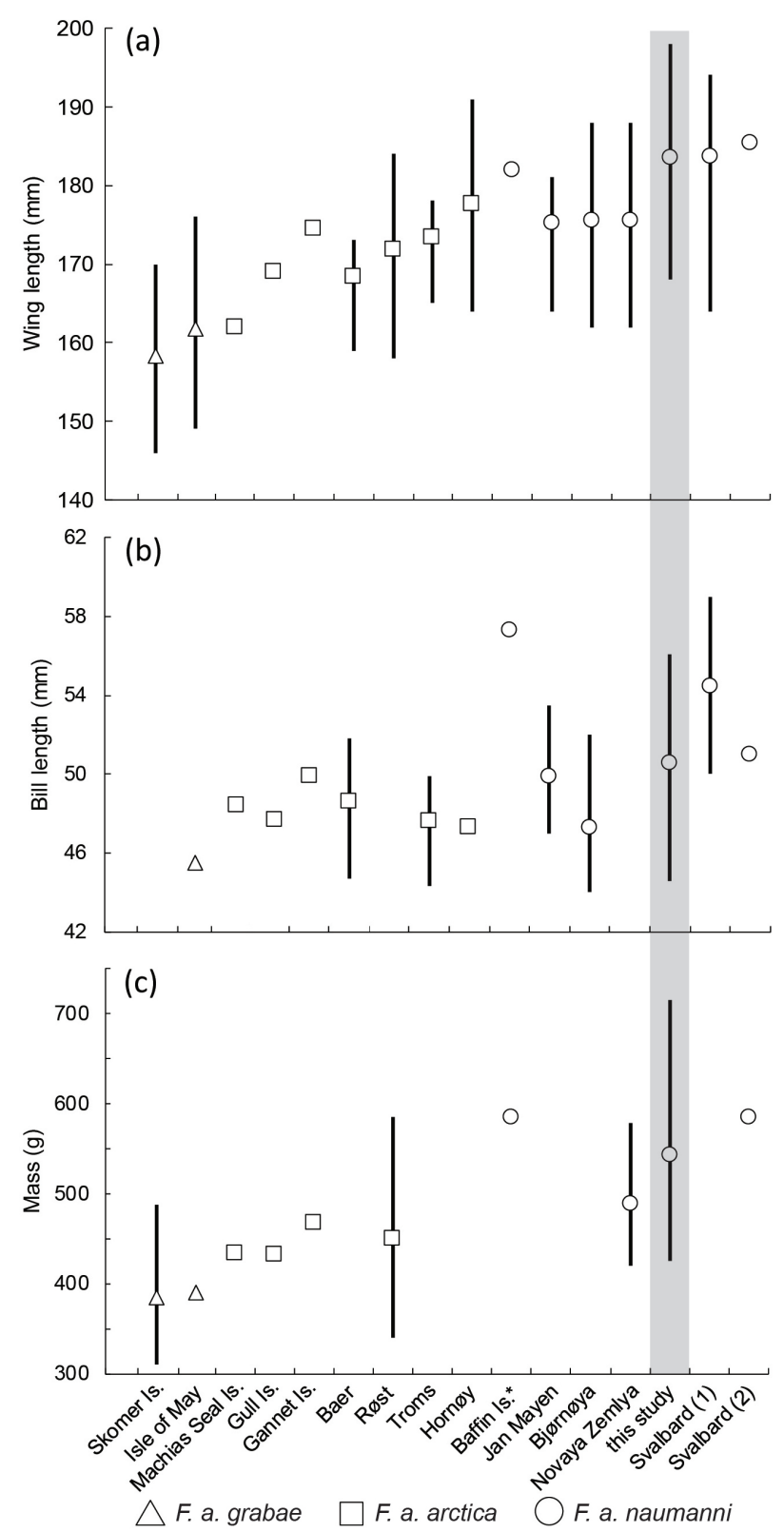

Fig. 4 Measurements for (a) wing length, (b) bill length and (c) mass of Atlantic puffins from Fratercula a. grabae, arctica and naumanni colonies arranged left to right by subspecies and latitude. Symbol indicates the mean, and bars indicate the range. Measurements are not available for all locations and have been left blank. See Fig. 1 for locations of colonies and Table 2 for exact means, ranges and sources of data. Svalbard (1) is from Le Roi (1911), and Svalbard (2) is from Underwood (2019). The asterisk indicates a single individual. Measurements from this study are shaded.

are debated for puffins but may include a combination of ocean and air temperature changes (both at breeding and winter grounds) and food quality variation (e.g., Moen 1991; Wojczulanis-Jakubas et al. 2011).
While clinal variation may explain the differences in body size between puffins in High-Arctic Greenland and populations in southern Greenland and southeast Canada, few samples also exist from intermediate latitudes in the western North Atlantic with which to confirm this trend. In west Greenland, the nearest large colony (>100 individuals) to our study area is ca. $525 \mathrm{~km}$ south, with about five small colonies ( $<10$ pairs) in-between and the largest breeding colonies ca. $1000 \mathrm{~km}$ farther south (Boertmann et al. 1996; Boertmann \& Huffeldt 2012). To the west, the nearest colony, on Coburg Island, Canada, is ca. $240 \mathrm{~km}$ away (thought to be naummani) and was first documented in 1998 (Robards et al. 2000). No morphometric data are available from these colonies. Between the Coburg Island colony and the large colonies in Newfoundland, over $2500 \mathrm{~km}$ distant, few $(<10)$ small colonies are known or thought to exist (Nettleship \& Evans 1985; Gaston \& Provencher 2012; Sabina 2017; eBird 2020; Lowther et al. 2020) and no morphometric data are available (Fig. 1). The relative geographic isolation of the puffin population in High-Arctic Greenland (including Coburg Island) is perhaps best compared to the main group of islands in the Svalbard Archipelago and to Iceland, which are ca. $300 \mathrm{~km}$ (Bjørnøya) and ca. $450 \mathrm{~km}$ (Faroe Islands) from the next nearest populations, respectively. However, Svalbard has an estimated 50 colonies and 10000 puffin pairs (Harris \& Wanless 2011), and Iceland has an estimated 800 colonies and 3-4 million pairs (Burfield \& van Bommel 2004), substantially more than the eight or so colonies and 150-250 pairs (K. Burnham, unpubl. data), including Coburg Island, in all of High-Arctic Greenland.

Salomonsen (1935) previously noted the presence of exceptionally small individual puffins, "mutants," in naumanni colonies in Svalbard and Novaya Zemlya (also see Kolthoff 1903; Le Roi 1911). He suggested they comprised between $5 \%$ and $10 \%$ of the population and believed these individuals to be naumanni, but "genotypically different" and "primitive" (Salomonsen 1935). In our study, two females and two males (ca. 9\% of our samples) appear to fit this description (Fig. 5). The two females have the smallest recorded wing and bill lengths (and mass for one), while the two males have the smallest wing, bill and mass measurements amongst males. While these small puffins may be genotypically different, it is also plausible that they emigrated from more southern colonies that have small body size. Although nest site fidelity of adults is extremely high in puffins, natal dispersal has been shown to be highly variable, and the longest documented juvenile dispersal (ca. $550 \mathrm{~km}$ ) is similar in distance as from our study area to the nearest large colony to the south (Harris 1983; Harris \& Wanless 1991; Breton et al. 2006; Sandvik et al. 2008). 

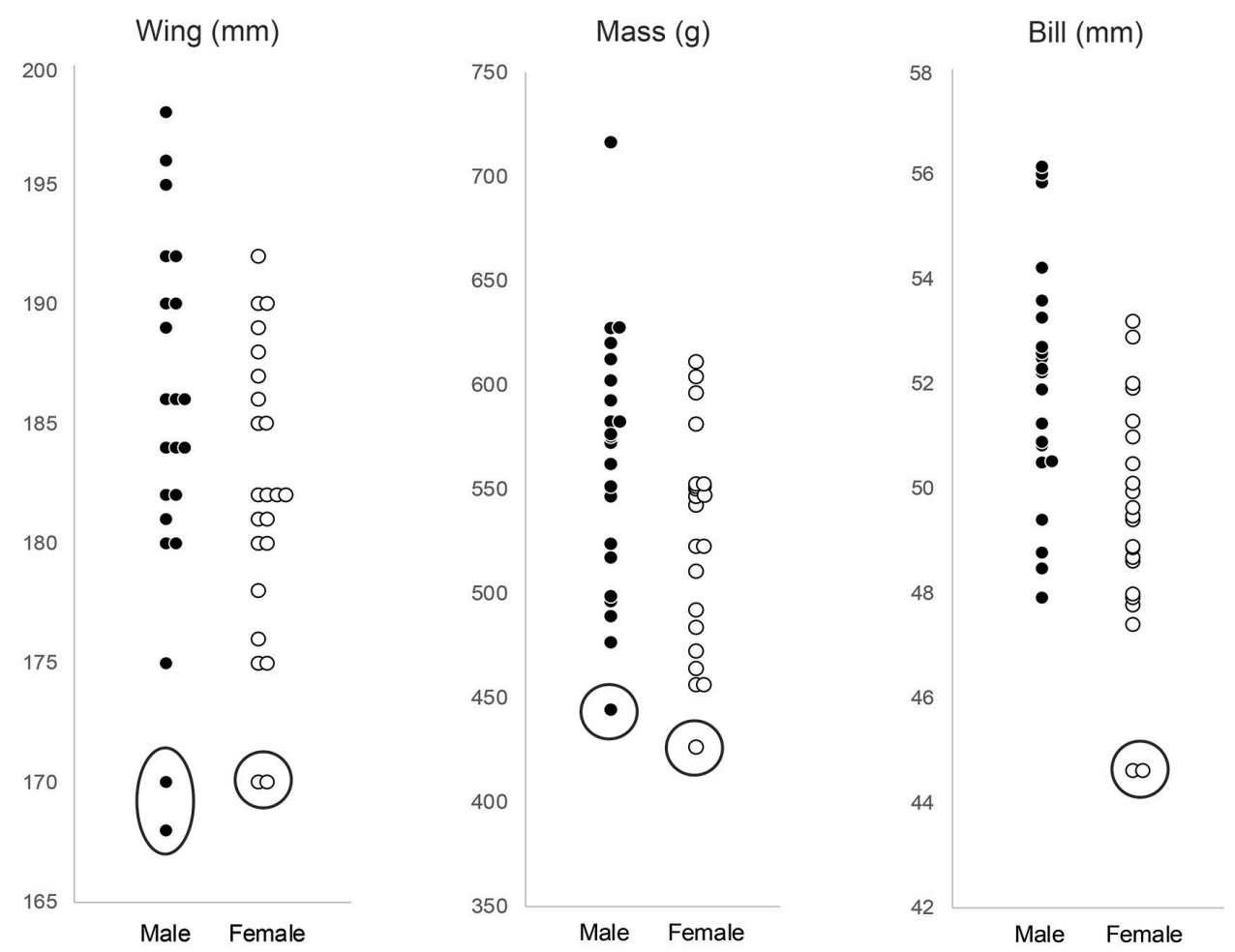

Fig. 5 Measurements of individual Atlantic puffins captured at Dalrymple Rock. Circled samples indicate individuals which may meet Salomonsen's (1935) definition of "mutant."

However, as Salomonsen (1935) points out, if dispersal is occurring, then why would it only be south to north, as no naumanni-sized individuals have been recorded during the breeding season at more southern colonies.

Speciation in seabirds has been well studied, and multiple mechanisms have been identified as playing significant roles (e.g., Friesen et al. 2007; Friesen 2015; Lombal et al. 2020). For example, Friesen et al. (2007) suggest that genetic structure in migratory seabirds is likely a result of species that have multiple population-specific non-breeding (wintering) areas. This fits well for what is known on other North Atlantic auk species, such as thick-billed murre and little auk, which show little genetic differentiation between colonies and which have varying degrees of overlap in wintering areas (Fort et al. 2013; Wojczulanis-Jakubas et al. 2014; Tigano et al. 2015; Frederiksen et al. 2016). Unfortunately, data for puffins are much more limited, and the only genetic analysis carried out to date was between three colonies in Iceland and, in the UK, the Isle of May and Hermaness (Moen 1991). Results showed no genetic differentiation between colonies in Iceland, the Isle of May and Hermaness, and the wintering area for Isle of May puffins partially overlapped with those of Icelandic colonies (no data for wintering area of Hermaness colony;
Moen 1991; Harris et al. 2010; Fayet et al. 2017). While no large-scale genetic analysis of puffin colonies in the North Atlantic has been undertaken, Fayet et al. (2017) provide data on wintering areas of both North American and European colonies. Results showed a high degree of overlap in wintering areas, which would suggest little genetic differentiation may exist between colonies (see Friesen et al. 2007). No winter range data have been published for puffins from High-Arctic Greenland, or any other naumanni population, and it is therefore unknown if their winter range overlaps with those of more southern colonies.

\section{Conclusion}

That puffins from High-Arctic Greenland are morphologically different from (i.e., larger than) those found at more southern latitudes is in no doubt. Furthermore, as there are no puffin colonies directly to the south in Greenland or to the south-west in Canada, it appears the puffin population in High-Arctic Greenland is also relatively geographically isolated, yet the large variation in morphometric measurements suggests connections with populations to the south. While the reported differences in morphology and the apparent geographic isolation 
of High-Arctic Greenland puffins are supportive of the naumanni subspecies, genetic analyses are needed to elucidate whether there is differentiation between puffin populations within and between subspecies.

\section{Acknowledgements}

The authors thank Bridger Konkel, Calen Offield, Julie Konkel, Fallon Meyer, Sarah Baugh and Claire Behnke for assistance in the field. Logistics help was provided by Polar Field Services and Jessy Jenkins and Kim Derry, the Idaho Bureau of Land Management and Virginia Hoffman, the United States Air Force, the 109th Air National Guard and the National Science Foundation. Permits were provided by the Greenland Home Rule Government. Special thanks go to the residents of Thule Air Base for their assistance in supporting our research. Two anonymous reviewers provided helpful comments that improved this article. All applicable ethical guidelines for the use of birds in research have been followed, including those presented in the Ornithological Council's Guidelines to the use of wild birds in research (Fair et al. 2010).

\section{Funding}

Funding was provided by The Offield Family Foundation, Wolf Creek Charitable Trust, Augustana College, Patagonia, University of North Texas, Trout/Jarvis Family, Cafferty Family, Kim Pelle and additional donors to the High Arctic Institute.

\section{Disclosure statement}

The authors report no potential conflict of interest.

\section{References}

Anker-Nilssen T., Jens-Kjeld J. \& Harris M.P. 2018. Fit is fat: winter body mass of Atlantic puffins Fratercula arctica. Bird Study 65, 451-457,doi: 10.1080/00063657.2018.1524452.

Ashton K.G. 2002. Patterns of within-species body size variation of birds: strong evidence for Bergmann's rule. Global Ecology $\theta$ Biogeography 11, 505-523, doi: 10.1046/j.1466822X.2002.00313.x.

Baillie S.M. \& Jones I.L. 2003. Atlantic puffin (Fratercula arctica) chick diet and reproductive performance at colonies with high and low capelin (Mallotus villosus) abundance. Canadian Journal of Zoology 81, 1598-1607, doi: 10.1139/ z03-145.

Barrett R.T., Anker-Nilssen T. \& Krasnov Y.V. 1997. Can Norwegian and Russian razorbills Alca torda be identified by their measurements? Marine Ornithology 25, 5-8.
Barrett R.T., Fieler R., Anker-Nilssen T. \& Rikardsen F. 1985. Measurements and weight changes of Norwegian adult puffins Fratercula arctica and kittiwakes Rissa tridactyla during the breeding season. Ringing o Migration 6, 102-112, doi: 10.1080/03078698.1985.9673865.

Barrett R.T., Nilsen E.B. \& Anker-Nilssen T. 2012. Long-term decline in eggs size of Atlantic puffins Fratercula arctica is related to changes in forage fish stocks and climate conditions. Marine Ecology Progress Series 457, 1-10, doi: 10.3354/ meps09813.

Bédard J. 1985. Evolution and characteristics of the Atlantic Alcidae. In D.N. Nettleship \& T.R. Birkhead (eds.): The Atlantic Alcidae. Pp. 1-51. London: Academic Press.

Berglund P.A. \& Hentati-Sundberg J. 2015. Arctic seabirds breeding in the African-Eurasion Waterbird Agreement (AEWA) area: status and trends 2014. CAFF Assessment Series Report 13. Akureyri, Iceland: Conservation of Arctic Flora and Fauna International Secretariat.

Bergmann C. 1847. Ueber die verhältnisse der wärmeökonomie der thiere $\mathrm{zu}$ ihrer grösse. (On the relationship between the thermal economy of animals and their size.) Gottinger Studien 3, 595-708.

BirdLife International 2020. Species factsheet: Fratercula arctica. Accessed on the internet at http://www.birdlife.org on 24 March 2020.

Boertmann D. 1994. An annotated checklist to the birds of Greenland. Monographs on Greenland, Bioscience 38. Copenhagen: University of Copenhagen.

Boertmann D. 2007. Greenland's Red List. Aarhus, Denmark: National Environmental Research Institute, Dept. of Arctic Environment, Aarhus University.

Boertmann D. \& Huffeldt N.P. 2012. Seabird colonies in the Melville Bay, northwest Greenland. Scientific Report from DCE—Danish Centre for Environment and Energy 45. Aarhus, Denmark: Danish Centre for Environment and Energy, Aarhus University.

Boertmann D., Merkel F. \& Gilg O. 2020. Seabird breeding colonies in east and north Greenland: a baseline. Arctic 73, 20-39, doi: 10.14430/arctic69885.

Boertmann D.A., Mosbech A., Falk K. \& Kampp K. 1996. Seabird colonies in western Greenland $\left(60^{\circ}-79^{\circ} 30^{\prime} \mathrm{N}\right.$. lat). NERI Technical Report 170. Copenhagen: National Environmental Research Institute.

Bond A.L., Standen R.A., Diamond A.W. \& Hobson K.A. 2016. Sexual size dimorphism and discriminant functions for predicting the sex of Atlantic Puffin (Fratercula arctica). Journal of Ornithology 157, 875-883, doi: 10.1007/ s10336-016-1332-8.

Breton A.R., Diamond A.W. \& Kress S.W. 2006. Encounter, survival, and movement probabilities from an Atlantic puffin (Fratercula arctica) metapopulation. Ecological Monographs 76, 133-149, doi: 10.1890/05-0704.

Burfield I. \& van Bommel F. 2004. Birds in Europe (population estimates, trends, and conservation status). Cambridge, UK: Birdlife International.

Burnham J.L. \& Burnham K.K. 2010. An ornithological survey of the Carey Islands, northwest Greenland. Dansk Ornitologisk Forenings Tidsskrift 104, 26-37. 
Butler R.G., Buckley D.E., Nettleship D.N., Boesman P.F.D. \& Garcia E.F.J. 2020. Black guillemot (Cepphus grylle), version 1.0. In S.M. Billerman (ed.): Birds of the world. Ithaca, NY: Cornell Lab of Ornithology. Accessed on the internet at https://doi.org/10.2173/bow.blkgui.01 on 4 Oct 2020.

Camphuysen C.J. 1989. Biometrics of auks at Jan Mayen. Seabird 12, 7-10.

Corkhill P. 1972. Measurements of puffins as criteria of sex and age. Bird Study 19, 193-201, doi: 10.1080/000636 57209476343.

de Korte J. 1972. Birds, observed and collected by "De Nederlandse Spitsbergen Expeditie" in west and east Spitsbergen, 1967 and 1968-'69; third and last part. Beaufortia 261, 23-58.

Dement'ev G.P., Meklenburtsev R.N., Sudilovskaya A.M. \& Spangerberg E.P. (eds.) 1951. Birds of the Soviet Union. Jerusalem: Israel Program for Scientific Translations.

eBird 2020. An online database of bird distribution and abundance. (Web application.) Ithaca, NY: Cornell Lab of Ornithology. Accessed in the internet at http://www.ebird.org on 7 October 2020.

Fair J.M., Paul E. \& Jones J. (eds.) 2010. Guidelines to the use of wild birds in research. 3rd edn. Washington, DC: Ornithological Council.

Fayet A.L., Freeman R., Anker-Nilssen T., Diamond A., Erikstad K.E., Fifield D., Fitzsimmons M.G., Hansen E.S., Harris M.P., Jessop M., Kouwenberg A., Kress S., Mowat S., Perrins C.M., Petersen A., Petersen I.K., Reiertsen T.K., Robertson G.J., Shannon P., Sigurðsson I.A., Shoji A., Wanless S. \& Guilford T. 2017. Ocean-wide drivers of migration strategies and their influence on population breeding performance in a declining seabird. Current Biology 27, 3871-3878, doi: 10.1016/j.cub.2017.11.009.

Fort J., Moe B., Strøm H., Grémillet D., Welcker J., Schultner J., Jerstad K., Johansen K.L., Phillips R.A. \& Mosbech A. 2013. Multicolony tracking reveals potential threats to little auks wintering in the North Atlantic from marine pollution and shrinking sea ice cover. Diversity and Distributions 19, 1322-1332, doi: 10.1111/ddi.12105.

Frederiksen M., Descamps S., Erikstad K.E., Gaston A.J., Gilchrist H.G., Grémillet D., Johansen K.L., Kolbeinsson Y., Linnebjerg J.F., Mallory M.L., Tranquilla L.A.M., Merkel F.R., Montevecchi W.A., Mosbech A., Reiertsen T.K., Robertson G.J., Steen H., Strøm H. \& Thørarinsson T.L. 2016. Migration and wintering of a declining seabird, the thick-billed murre Uria lomvia, on an ocean basin scale: conservation implications. Biological Conservation 200, 26-35, doi: 10.1016/j.biocon.2016.05.011.

Friars K.A. \& Diamond A.W. 2011. Predicting the sex of Atlantic puffins, Fratercula arctica, by discriminant analysis. Waterbirds 34, 304-311, doi: 10.1675/063.034.0305.

Fridolfsson A.-K. \& Ellegren H. 1999. A simple and universal method for molecular sexing of non-ratite birds. Journal of Avian Biology 30, 116-121, doi: 10.2307/3677252.

Friesen V.L. 2015. Speciation in seabirds: why are there so many species ... and why aren't there more? Journal of Ornithology 156, 27-39, doi: 10.1007/s10336-015-1235-0.
Friesen V.L., Burg T.M. \& McCoy K.D. 2007. Mechanisms of population differentiation in seabirds. Molecular Ecology 16, 1765-1785, doi: 10.1111/j.1365-294x.2006.03197.x.

Gosler A.J. 2004. Birds in the hand. In W.J. Sutherland et al. (eds.): Bird ecology and conservation: a handbook of techniques. Pp. 85-118. Oxford: Oxford University Press.

Gaston A.J. \& Jones I.L. 1998. The auks. Oxford: Oxford University Press.

Gaston A.J. \& Pipfner J.M. 2020. Thick-billed murre (Uria lomvia), version 1.0. In S.M. Billerman (ed.): Birds of the world. Ithaca, NY: Cornell Lab of Ornithology. Accessed on the internet at https://doi.org/10.2173/bow.thbmur.01 on 4 Oct 2020.

Gaston A.J. \& Provencher J. 2012. A specimen of the High Arctic subspecies of Atlantic puffin, Fratercula arctica naumanni, in Canada. Canadian Field Naturalist 126, 50- 54, doi: 10.22621/cfn.v126il.1297.

Hansen E.S. \& Garðarsson A. 2009. The Atlantic puffin population size of the Westman Islands, Iceland. In E. Stienen et al. (eds.): Seabird Group. 10th International Conference. Book of Abstracts. Brugge, Belgium. 27-30 March 2009. VLIZ Special Publication 42. Communications of the Research Institute for Nature and Forest - INBO.M.2009.1. P. 30. Brussels and Oostende: Belgium Research Institute for Nature and Forest / Flanders Marine Institute (VLIZ).

Harris M.P. 1979. Measurements and weights of British puffins. Bird Study 26, 179-186, doi: 10.1080/00063657909476636.

Harris M.P. 1980. Post-mortem shrinkage of wing and bill of puffins. Ringing and Migration 3, 60-61, doi: 10.1080/0307 8698.1980.9673765.

Harris M.P. 1981. Age determination and first breeding of British puffins. British Birds 74, 246-256.

Harris M.P. 1983. Biology and survival of the immature puffin Fratercula arctica. IBIS 125, 56-73, doi: $10.1111 / \mathrm{j} .1474-$ 919X.1983.tb03083.x.

Harris M.P. 1984. The puffin. London: T \& AD Poyser.

Harris M.P., Daunt F., Newell M., Phillips R.A. \& Wanless S. 2010. Wintering areas of adult Atlantic puffins Fratercula arctica from a North Sea colony as revealed by geolocation technology. Marine Biology 157, 827-836, doi: 10.1007/s00227-009-365-0.

Harris M.P. \& Wanless S. 1991. Population studies and conservation of puffins Fratercula arctica. In C.M. Perrins et al. (eds): Bird population studies. Pp. 230-248. Oxford: Oxford University Press.

Harris M.P. \& Wanless S. 2011. The puffin. London: T \& AD Poyser.

Holgersen H. 1953. On a collection of birds from Jan Mayen. Astarte 5, 1-9.

Kolthoff G. 1903. Bidrag till kännedom om norra polartrakternas däggdjur och fäglar. (Contribution to knowledge about the mammals and birds of the Arctic.) Kungliga Svenska Betenskaps-Akademiens Handlingar 36(9). Stockholm: P.A. Norstedt \& Söner.

Kurvits T., Alfthan B. \& Mork E. (eds). 2010. Arctic biodiversity trends 2010 — selected indicators of change. Akureyri, Iceland: Conservation of Arctic Flora and Fauna International Secretariat. 
Lavers J., Hipfner J.M. \& Chapdelaine G. 2020. Razorbill (Alca torda), version 1.0. In S.M. Billerman (ed.): Birds of the world. Ithaca, NY: Cornell Lab of Ornithology. Accessed on the internet at https://doi.org/10.2173/bow.razorb.01 on 4 Oct 2020.

Le Roi O. 1911. Die avifauna der Bären-Insel und des Spitzbergen-Archipels. (The avifauna of Bjørnøya and the Spitsbergen Archipelago.) In A. Koenig (ed.): Avifauna Spitzbergensis. (Avifaua of Spitsbergen.) Pp. 113-294. Berlin: W. Junk.

Lombal A.J., O'dwyer J.E., Friesen V., Woehler E.J. \& Burridge C.P. 2020. Identifying mechanisms of genetic differentiation among populations in vagile species: historical factors dominate genetic differentiation in seabirds. Biological Reviews 95, 625-651, doi: 10.1111/brv.12580.

Lowther P.E., Diamond A.W., Kress S.W., Robertson G.J., Russell K., Nettleship D.N., Kirwan G.M., Christie D.A., Sharpe C.J., Garcia E.F.J. \& Boesman P.F.D. 2020. Atlantic puffin (Fratercula arctica), version 1.0. In S.M. Billerman (ed): Birds of the world. Ithaca, NY: Cornell Lab of Ornithology. Accessed on the internet at https://doi.org/10.2173/ bow.atlpuf.01 on 4 Oct 2020.

Meiri S. \& Dayan T. 2003. On the validity of Bergmann's rule. Journal of Biogeography 30, 331-351, doi: 10.1046/j. 1365-2699.2003.00837.x.

Moen S.M. 1991. Morphological and genetic variation among breeding colonies of the Atlantic puffin (Fratercula arctica). Auk 108, 755-763, doi: 10.1093/auk/108.4.755.

Myrberget S. 1963. Systematic position of Fratercula arctica from a north Norwegian colony. Norwegian Journal of Zoology $11,74-84$.

Nettleship D.A. \& Evans P.G.H. 1985. Distribution and status of the Atlantic Alcidae. In D.N. Nettleship \& T.R. Birkhead (eds.): The Atlantic Alcidae. Pp. 54-149. London: Academic Press.

Petersen A. 1976. Size variables in puffins Fratercula arctica from Iceland, and bill features as criteria of age. Ornis Scandinavica 7, 185-192, doi: 10.2307/3676188.

Pethon P. 1967. The systematic position of the Norwegian common murre Uria aalge and puffin Fratercula arctica. Meddelelser fra det Zoologiske Museum, Oslo 80, 84-95.

Robards M., Gilchrist H.G. \& Allard K. 2000. Breeding Atlantic puffins, Fratercula arctica, and other bird species of Coburg Island, Nunavut. Canadian Field Naturalist 114, 72-77.
Salomonsen F. 1935. Aves. In S.L. Tuxen et al. (eds.): The zoology of the Faroes. Vol. 3. Part 2. Copenhagen: A.F. Høst \& Søn.

Salomonsen F. 1944. The Atlantic Alcidae. Göteborg: Wettergren \& Kerber.

Salomonsen F. 1950. Gronlands fugle. (Birds of Greenland.) Copenhagen: Munksgaard.

Sabina W. 2017. CWS: Waterbird colony database (Atlantic region). Version 1. In OBIS Canada Digital Collections. Bedford Institute of Oceanography, Dartmouth, NS, Canada. Accessed on the internet at https://doi. org/10.15468/vlrjfx accessed via GBIF.org on 2020-0504 on 4 May 2020.

Sandvik H., Erikstad K.E., Fauchald P. \& Tverra T. 2008. High survival of immatures in a long-lived seabird: insights from a long-term study of the Atlantic puffin (Fratercula arctica). Auk 125, 423-730, doi: 10.1525/auk. 2008.07059.

Schaanning H.T.L. 1933. Zoological results of the Norwegian scientific expedition to East-Greenland I: a contribution to the bird fauna of Jan Mayen. Skrifter om Svalbard og Ishavet 49, 25-39.

Tigano, A., Damus M, Birt T.P., Morris-Pocock J.A., Artukhin Y.B. \& Friesen V.L. 2015. The Arctic: glacial refugium or area of secondary contact? Inference from the population genetic structure of the thick-billed murre (Uria lomvia), with implication for management. Journal of Heredity 106, 238-246, doi: 10.1093/jhered/esv016.

Underwood A.K.P. 2019. Toxicology of the Svalbard Atlantic puffin. Master's thesis, UiT The Arctic University of Norway, Tromsø, Norway.

Vaurie C. 1965. The birds of the Palearctic fauna: non-passeriformes. London: H.F. \& G. Witherby Limited.

Wojczulanis-Jakubas K., Jakubas D., Welcker J., Harding A.M.A., Karnovsky N.J., Kidawa D., Steen H., Stempniewics L. \& Camphuysen C.J. 2011 . Body size variation of a High-Arctic seabird: the dovekie (Alle alle). Polar Biology 34, 847-854, doi: 10.1007/s00300-010-0941-6.

Wojczulanis-Jakubas K., Kilikowska A., Harding A.M.A., Jakubas D., Karnovsky N.J., Steen H., Strøm H., Welcker J., Gavrilo M., Lifjeld J.T. \& Johnsen A. 2014. Weak population genetic differentiation in the most numerous Arctic seabird, the little auk. Polar Biology 37, 621-630, doi: 10.1007/s00300-014-1462-5. 